\title{
From wind to whales: trophic links in a coastal upwelling system
}

\author{
Donald A. Croll ${ }^{1, *}$, Baldo Marinovic ${ }^{1}$, Scott Benson ${ }^{2}$, Francisco P. Chavez ${ }^{3}$, \\ Nancy Black ${ }^{4}$, Richard Ternullo ${ }^{4}$, Bernie R. Tershy ${ }^{1}$ \\ ${ }^{1}$ Center for Ocean Health, Long Marine Laboratory, 100 Shaffer Road, University of California Santa Cruz, \\ Santa Cruz, California 95060, USA \\ ${ }^{2}$ Moss Landing Marine Laboratories, PO Box 450, Moss Landing, California 95039, USA \\ ${ }^{3}$ Monterey Bay Aquarium Research Institute, PO Box 628, Moss Landing, California 95039, USA \\ ${ }^{4}$ Monterey Bay Dolphin Project, 84 Fisherman's Wharf, Monterey, California 93940, USA
}

\begin{abstract}
Blue whales Balaenoptera musculus meet the highest prey demands of any predator that has ever existed by feeding exclusively upon dense but patchy schools of pelagic euphausiids. We examined the role that seasonally high primary production supported by coastal upwelling combined with topographic breaks off California play in creating, collecting, and maintaining euphausiids at densities sufficient to allow exploitation by whales. We used concurrent ship- and mooringbased oceanographic, hydroacoustic, and net sampling, whale-sighting records, visual surveys, and time-depth recorder deployment to examine temporal and spatial linkages between (1) intensity of upwelling, (2) primary production, (3) development, density and distribution of euphausiids, and (4) the distribution, abundance, and foraging behavior of blue whales in Monterey Bay, California between 1992 and 1996. Blue whales fed exclusively upon adult euphausiids Thysanoessa spinifera and Euphausia pacifica that were larger than those generally available in the Bay. Foraging whales dove repeatedly to dense euphausiid aggregations between 150 and $200 \mathrm{~m}$ on the edge of the Monterey Bay Submarine Canyon. Euphausiid aggregations where whales were foraging averaged $153 \mathrm{~g} \mathrm{~m}^{-3}$, approximately 2 orders of magnitude greater than mean euphausiid densities in the Bay $\left(1.3 \mathrm{~g} \mathrm{~m}^{-3}\right)$. High euphausiid densities are supported by high primary production between April and August (249 $\mathrm{mg} \mathrm{C} \mathrm{m}^{-3} \mathrm{~d}^{-1}$ ) and a submarine canyon that provides deep water down-current from an upwelling region. Peak euphausiid densities occur in late summer/early fall, lagging the seasonal increase in primary production by 3 to 4 mo. This lag results from the temporal development of euphausiids spawned around the spring increase in primary production and the shoreward collapse of productivity due to decreased upwelling in late summer. The migratory movements of the California blue whale probably reflect seasonal patterns in productivity in other foraging areas similar to those we describe for Monterey Bay.
\end{abstract}

KEY WORDS: Pelagic $\cdot$ Foraging ecology $\cdot$ Predation $\cdot$ Blue whale $\cdot$ Upwelling

Resale or republication not permitted without written consent of the publisher

\section{INTRODUCTION}

A major goal in ecology is to measure the role of biotic and abiotic factors in determining the distribution and abundance of populations. While numerous empirical studies of terrestrial, freshwater, and nearshore systems have been conducted (e.g. Paine 1966, Estes et al. 1978, Erlinge et al. 1984, Terborg 1988, Carpenter \& Kitchell 1993, Polis et al. 1997, 1998, Terborg et al. 1999, Carpenter et al. 2001), similar studies are rare for pelagic marine systems (Venrick 1990). This is particularly true for large pelagic predators such as marine mammals, seabirds and predatory fishes. This paucity of knowledge largely stems from the difficulty of simultaneously measuring the distribution and abundance of predators, grazers, primary producers, and environmental factors in the open ocean over appropriate temporal and spatial scales, and of con- 
ducting manipulative experiments in pelagic systems. As a result, pelagic studies often correlate distribution and abundance patterns of oceanic predators to indirect indices of prey abundance such as surface chlorophyll or water temperature (e.g. Harrison et al. 1990, Elphick \& Hunt 1993, Kenney et al. 1995, Tynan 1998) with limited success (Horne \& Schneider 1994).

Recent advances in hydroacoustic assessment have allowed direct correlation of some pelagic predators and their prey (e.g. Croll et al. 1998, Fiedler et al. 1998, Mehlum et al. 1998, Russell et al. 1999, Simard \& Lavoie 1999). However, the mechanisms through which physical forcing, primary productivity, aggregations of prey and predators are linked (e.g. transport, reproduction, growth and development) are rarely simultaneously measured. This is particularly true for large pelagic marine predators such as marine mammals (Whitehead \& Glass 1985, Payne et al. 1990, Boyd \& Arnbom 1991, Piatt \& Methaven 1992, Winn et al. 1995, Bowen 1997, Hooker et al. 1999). Most marine mammals are apex carnivores adapted to feed on dense, patchily distributed aggregations of schooling prey (Gaskin 1982, Riedman 1990).

The blue whale is the largest animal that has ever existed: adults in the Antarctic have reached a maximum body length of $33 \mathrm{~m}$ and body mass of $150000 \mathrm{~kg}$ (Yochem \& Leatherwood 1985). With their mammalian metabolic rate, they have the highest prey demands of any predator that has ever existed, up to $2 \mathrm{t} \mathrm{d}^{-1}$ (Rice 1978). They satisfy this demand by feeding on spatially and temporally ephemeral aggregations of high densities of euphausiids (Tomilin 1967, Yochem \& Leatherwood 1985, Schoenherr 1991, Gendron 1992, Tershy 1992, Croll et al. 1998, Fiedler et al. 1998, Simard \& Lavoie 1999). Blue whales off California seasonally forage upon dense euphausiid schools in highly productive coastal upwelling regions (Schoenherr 1991, Croll et al. 1998, Fiedler et al. 1998, Forney \& Barlow 1998). Croll et al. (1998) proposed that (1) the distribution of this blue whale population is defined by their attraction to areas of predictably high densities of euphausiids (Euphausia pacifica, Thysanoessa spinifera and $\mathrm{Nyc}$ tiphanes simplex) concentrated at discrete depths in the water column, (2) these areas of high euphausiid density are sustained by upwelling regions of seasonally high primary production, and (3) topographic breaks in the continental shelf located down-current from these regions work in concert with euphausiid behavior to collect and maintain large concentrations of euphausiids.

In this study, we examine these predictions for California blue whales feeding in a well-defined foraging area (Monterey Bay, California) over several years. Specifically, we examine temporal and spatial linkages between (1) the intensity of wind-driven upwelling, (2) the distribution and magnitude of primary production, (3) the growth, development, density and distribution of aggregations of grazing euphausiid prey, and (4) the distribution, abundance, and foraging behavior of blue whales within these aggregations. This is an ideal system in which to examine pelagic predator/prey relationships because blue whales forage as stenophagic predators on marine grazers in a simplified food web (primary producers - grazers - apex predators).

\section{MATERIALS AND METHODS}

Study area. Monterey Bay, located on the central coast of California $\left(36^{\circ} 45^{\prime} \mathrm{N}, 122^{\circ} 00^{\prime} \mathrm{W}\right)$ (Fig. 1), is the largest bay (approximately $1200 \mathrm{~km}^{2}$ ) on the US west coast with unrestricted access to the open ocean. It is

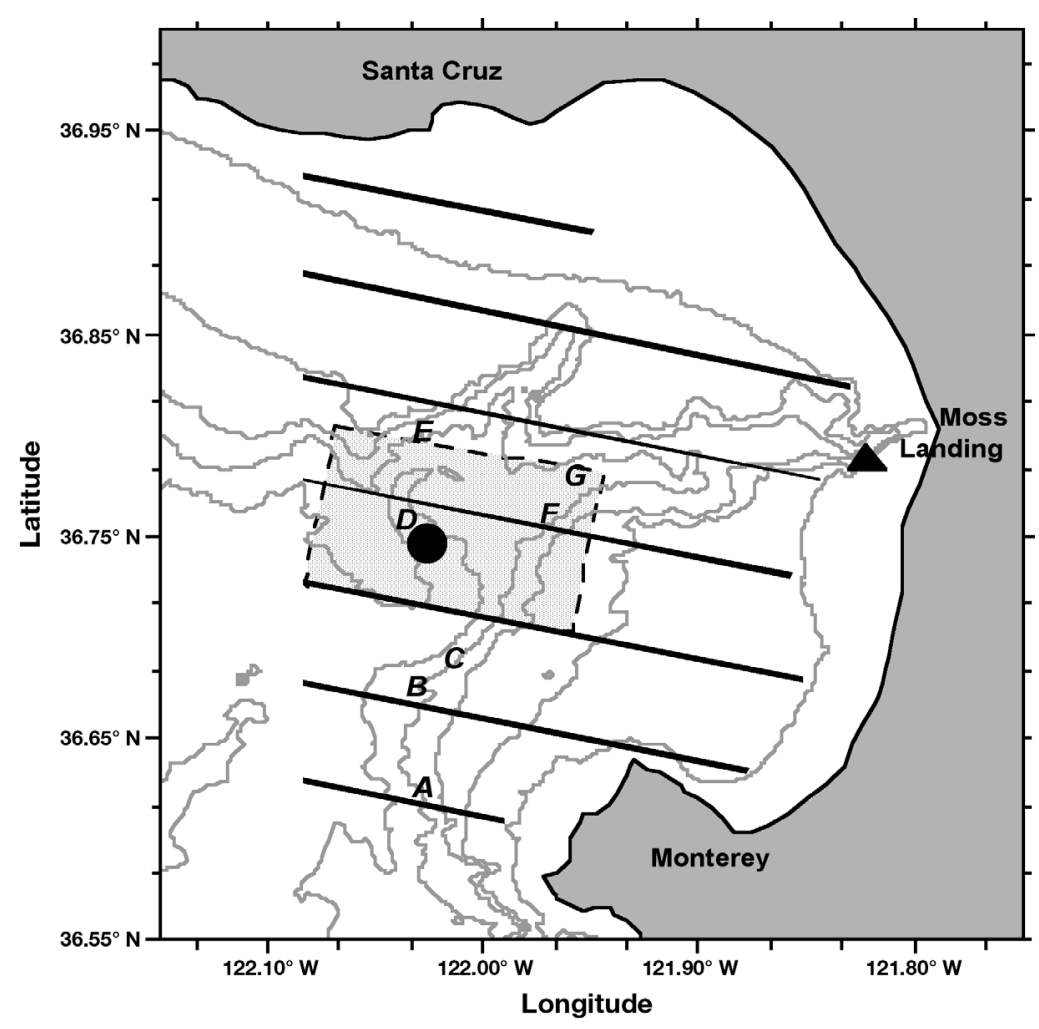

Fig. 1. Monterey Bay, California study area, showing systematic survey track lines. $(\boldsymbol{\Delta}, \mathbf{\Delta})$ Locations of oceanographic sampling stations M1 and C1, respectively. Shaded area: small-area survey region. A to G: zooplankton net sampling locations 
further distinguished by the presence of the Monterey Submarine Canyon, a canyon of similar dimensions to the Grand Canyon (Shepard 1973).

Whale distribution and abundance-opportunistic surveys. General patterns in the distribution and abundance of blue whales in Monterey Bay were assessed using data gathered opportunistically between 1992 and 1996 in regular commercial whale-watching trips. Trips departed from Monterey and were usually 4 to $5 \mathrm{~h}$ in duration. Typical cruises included 60 to $120 \mathrm{~min}$ in areas where whales (if present in the Bay) were generally found. Whale-watches usually emphasized the southern regions of Monterey Bay. Experienced observers recorded the location and number of blue whales sighted. Twice monthly averages of the number of blue whales sighted per trip were calculated for comparison with systematic survey data. For seasonal patterns in whale abundance, monthly averages of number of blue whales sighted trip ${ }^{-1}$ were calculated for all trips between 1992 and 1996.

Whale distribution and abundance-systematic surveys. Between August and November 1996, a total of 5 systematic whale surveys were conducted for comparison with relative abundance estimates from whalewatching trips. We ran 7 track lines 10 to $25 \mathrm{~km}$ in length and separated by $5.6 \mathrm{~km}$ at a ship speed of $18.5 \mathrm{~km} \mathrm{~h}^{-1}$ (10 knots) (Fig. 1). Surveys were conducted using standard line-transect methods for marine mammals developed by the US National Marine Fisheries Service (Barlow 1994). The location and number of all blue whales encountered from the track line out $90^{\circ}$ abeam were recorded by 3 marine mammal observers using $7 \times 50$ reticle binoculars from the flying bridge (5 $\mathrm{m}$ above sea level). Number of individuals, sightingcue, behavior, location, time and weather conditions were recorded at the time of each sighting. In addition, ship position along the track line was recorded every 10 min. Because all surveys were conducted in similar conditions, no adjustments were made for sea state. Whale density estimates were calculated using standard marine mammal line transect methods (Burnham et al. 1980, Buckland et al. 1993, Barlow 1994).

Whale foraging behavior. To examine whale diving behavior in relation to prey distribution, we attached microprocessor-controlled time-depth recorders (TDRs) (Wildlife Computers Mark 5) to 2 blue whales foraging in the study area (Croll et al. 1998). Dive depth (resolution $\pm 2 \mathrm{~m}$ ) was sampled every $1 \mathrm{~s}$. To account for shortduration shallow dives associated with respiration, only dives that exceeded $2 \mathrm{~min}$ in duration and $30 \mathrm{~m}$ depth were included for analysis of foraging dives. This convention was supported by 3 observations: (1) all short duration shallow dives took place within a series of surface respirations, (2) no echo returns attributable to euphausiids were observed in water less than
$30 \mathrm{~m}$ deep, and (3) zooplankton net hauls to less than $30 \mathrm{~m}$ did not contain euphausiids (see Croll et al. 2001 for review of traveling vs foraging dives in blue whales). Sampled dives were binned into $10 \mathrm{~m}$ bins and percent time at depth was calculated for each depth bin, excluding depths shallower than $20 \mathrm{~m}$. The diving behavior of foraging whales was correlated to the distribution and density of euphausiid prey schools by a series of small-area transects approximately $5.6 \mathrm{~km}$ long (3 nautical miles, $\mathrm{n}$ miles) covering an area of approximately $100 \mathrm{~km}^{2}$, centered on the tagged, foraging whales (Croll et al. 1998).

Whale diet. The species of prey taken by whales was determined through analysis of whale fecal samples collected opportunistically in the study region in August 1996. A total of 5 samples was collected with a dip net and preserved in $70 \%$ ethanol. In the laboratory, a well-mixed aliquot was taken of each fecal sample and all right mandibles of euphausiids were removed and classified to species using methods developed by Kieckhefer (1992). Length distribution of euphausiids was estimated from right-mandible lengths based upon linear regressions developed by Kieckhefer (1992).

Euphausiid distribution, abundance and composition. The horizontal distribution of euphausiids was measured concurrent with a systematic whale-abundance survey conducted on August 13 and 14, 1996. Acoustic backscatter was measured using a Simrad EY-500 echosounder operated at $200 \mathrm{kHz}$. The echosounder system was calibrated before and after the study using the standard sphere method (Johannesson \& Mitson 1983). Detailed descriptions of echosounder data analyses are presented in Croll et al. (1998) and Hewitt \& Demer (1993). For plotting prey distribution, an area backscattering coefficient $\left(\mathrm{m}^{2}\right.$ target $\mathrm{m}^{-2}$ sampling area integrated to a depth of $200 \mathrm{~m}$ ) was calculated from volume backscattering $\left(\mathrm{S}_{\mathrm{V}}\right)$ values for every $0.9 \mathrm{~km}(0.5 \mathrm{n}$ miles $)$ of the survey line.

From these large-area surveys, we identified a region of high euphausiid and whale density. Within this region we conducted a series of small-area surveys to measure euphausiid density and vertical distribution between August 19 and 22, 1996 (Fig. 1). We ran twentythree $3.7 \mathrm{~km}$ ( $2 \mathrm{n}$ miles) lines separated by $1.85 \mathrm{~km}$ (1 n mile) at a ship speed of $18.5 \mathrm{~km} \mathrm{~h}^{-1}$ (10 knots). Acoustic backscatter strength was measured as described above. The vertical distribution (10 $\mathrm{m}$ depth intervals) of euphausiid schools was measured using mean $\mathrm{s}_{\mathrm{A}}$ (scattering area coefficient) values averaged over every $0.93 \mathrm{~km}$ (0.5 n miles) of the survey trackline. Euphausiid school density in the whale foraging region was estimated using mean $\mathrm{s}_{\mathrm{A}}$ values averaged over every $0.93 \mathrm{~km}$ of survey trackline and euphausiid size distribution from net samples (see below). 
Identification of euphausiid schools in echograms was confirmed by targeted plankton tows utilizing paired, closing, $0.7 \mathrm{~m}$ bongo nets fitted with $333 \mu \mathrm{m}$ mesh. Oblique tows to $200 \mathrm{~m}$ were conducted such that 1 of the 2 bongo nets fished throughout the oblique tow while the second net was tripped to target depth layers of strong acoustic backscatter. Euphausiids were enumerated for the entire sample or a sub-split of the sample (minimum 200 individuals), identified to species and life history stage, and measured to the nearest millimeter. Euphausiid species composition from net samples was compared with species composition from whale fecal samples. In addition to these targeted tows in August 1996, 200 m oblique net samples were taken in May, August and September 1996 at the edge of the Monterey Submarine Canyon to examine seasonal changes in age composition of euphausiids.

Euphausiid size distribution from August net samples was used for hydroacoustic biomass estimates. Biomass estimates were calculated following the techniques described in Hewitt \& Demer (1993), incorporating euphausiid size distributions measured from bongo net tows. Adjustment of biomass estimates for transducer frequency was made following Greene et al. (1991). Numerical densities of krill (individuals $\mathrm{m}^{-3}$ ) were estimated from acoustic estimates of biomass density using species composition and size distribution from net tows and the allometric conversion of standard length to euphausiid weight derived for Euphausia superba (Hewitt \& Demer 1993).

Seasonal abundance of zooplankton. The seasonal abundance of zooplankton in Monterey Bay was tracked during 1996 using hourly averages of acoustic backscatter measured by a $75 \mathrm{kHz}$ Acoustic Doppler Current Profiler (ADCP) permanently mounted on a mooring (located at $122^{\circ} 01^{\prime} \mathrm{W}, 36^{\circ} 36^{\prime} \mathrm{N}$, Fig. 1), operating at $75 \mathrm{kHz}$. ADCP data have been used to provide relative estimates of zooplankton abundance through backscatter strength (e.g. Buchholz et al. 1995, Griffiths \& Diaz 1996), but are not able to accurately provide quantitative estimates of zooplankton abundance due to signalclipping and associated measurement bias (Brierly et al. 1998). Daily averages of 1996 ADCP volume backscatter were binned into $1 \mathrm{~m}$ bins and used to generate a seasonal comparison of zooplankton densities.

Oceanographic sampling. Detailed methods for oceanographic sampling have been described elsewhere (Pennington \& Chavez 2000). Briefly, shipboard time-series data were collected twice monthly between 1992 and 1996 aboard the RV 'Point Lobos' on single-day cruises. In this paper we report results from 2 of the stations occupied in Monterey Bay (C1, M1: Fig. 1). Conductivity/temperature/depth (CTD) casts were made to at least $200 \mathrm{~m}$ with a Sea-Bird 911 or $911+$ CTD mounted in a General Oceanics 12-place rosette with 51 Niskin bottles. Conductivity and temperature sensors were calibrated annually. Downcast data were binned to $1 \mathrm{~m}$ depth intervals, and upcast data were averaged following each bottle trip.

Rosette Niskin bottles were filled at the surface, 5, $15,30,50$ and $100 \mathrm{~m}$. Water from these samples was used to calculate integrated chlorophyll $a$ and primary production measurements. Chlorophyll a concentration (hereafter termed 'chlorophyll', mg chl m${ }^{-3}$ ) was assayed with the standard fluorometric procedure of Holm-Hansen et al. (1965). This method was modified such that plant pigments were filtered onto $25 \mathrm{~mm}$ Whatman G/FF filters and extracted in acetone in a freezer for 24 to $48 \mathrm{~h}$ (Venrick \& Hayward 1984, Chavez et al. 1991). Measurements were made on a Turner Model-10 fluorometer calibrated with commercial chlorophyll (Parsons et al. 1984). Primary production was estimated as carbon fixation (hereafter termed 'primary production', $\mathrm{mg} \mathrm{C} \mathrm{m}^{-3} \mathrm{~d}^{-1}$ ) for $100 \%$ light penetration depth (surface) using ${ }^{14} \mathrm{C}$-uptake methods described in Pennington \& Chavez (2000).

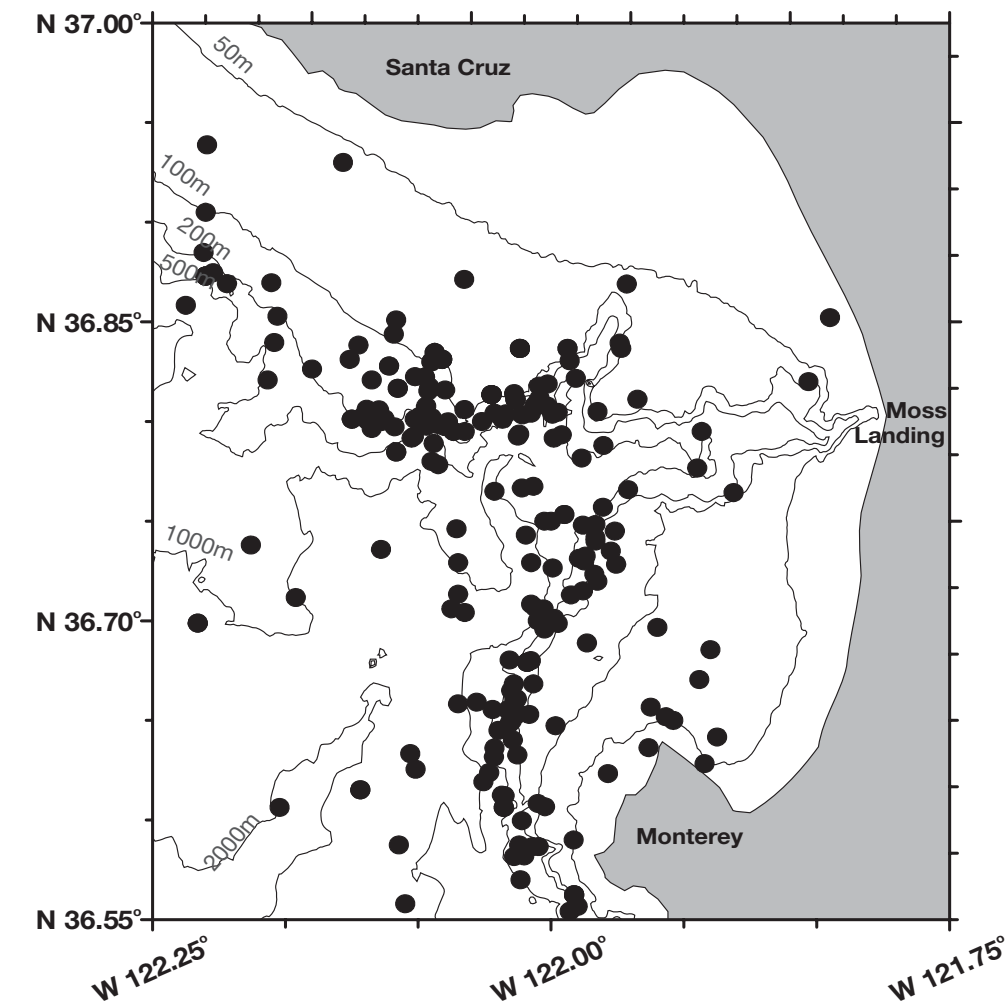

Fig. 2. Baleanoptera musculus. Locations of blue whales sighted during opportunistic whale-watch surveys between 1992 and 1996 in Monterey Bay, California 
Upwelling indices for the study region during the study period were obtained from the Pacific Fisheries Environmental Laboratory/NOAA website for $36^{\circ} \mathrm{N}$, $122^{\circ} \mathrm{W}$ (see www.pfeg.noaa.gov). The indices are based on estimates of offshore Ekman transport driven by geostrophic wind stress derived from 6-hourly, synoptic, surface atmospheric pressure fields (Bakun \& Nelson 1991). Twice monthly means of the daily upwelling indices were calculated. Unless otherwise noted, means \pm SD are reported.

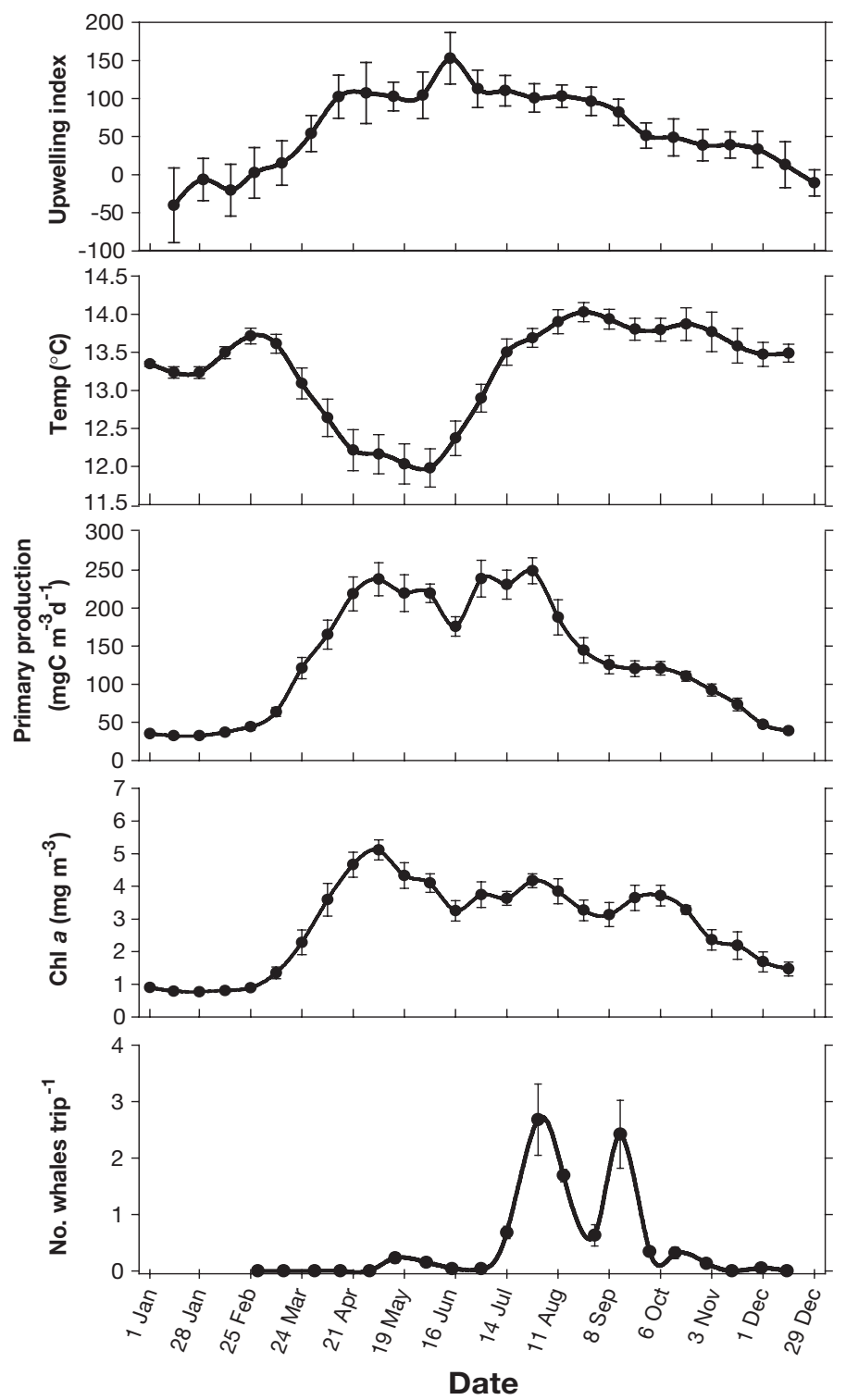

Fig. 3. Oceanographic climatology (mean $\pm \mathrm{SD}$ ) for Monterey Bay, California between 1992 and 1996, showing from top to bottom: Pacific Fisheries Environmental Laboratories/NOAA upwelling indices, sea-surface temperature, primary production at $100 \%$ light levels, integrated chlorophyll $a$, and number of whales Baleanoptera musculus per trip in opportunistic whale-watch surveys

\section{RESULTS}

\section{Whale distribution and abundance}

Blue whale sightings from whale-watch trips between 1992 and 1996 were concentrated along the edge of the Monterey Submarine Canyon (Fig. 2); blue whales were seasonally present in Monterey Bay between June and November (Fig. 3). Relative abundance estimates from whale-watch trips qualitatively tracked abundance estimates from systematic surveys (Fig. 4), and thus probably reflect the relative seasonal abundance of blue whales between 1992 and 1996. Systematic surveys revealed that blue whale density during the time period of peak abundance (August) was 0.034 whales $\mathrm{km}^{-2}(+0.056$ to $-0.204 \mathrm{SE})$.

\section{Whale foraging and diet}

We tagged 2 whales foraging during daylight hours (11:00 to $17: 00 \mathrm{~h})$ on the edge of Monterey Submarine Canyon with TDRs in 1996 (August 19 and 22, 1996). Foraging dive depths ranged from 144 to $176 \mathrm{~m}$ and 142 to $193 \mathrm{~m}$ in the 2 tagged whales, respectively. Mean maximum dive depth was $155( \pm 9.8) \mathrm{m}$ and 172 $( \pm 14.7) \mathrm{m}$, and mean dive durations were $8.8( \pm 0.8)$ min and $8.3( \pm 1.4) \mathrm{min}$, respectively. Both whales showed a stereotypical pattern, diving consistently and directly down to the 150 to 200 m layer in the water column and performing a series of 1 to 4,20 to $30 \mathrm{~m}$ vertical excursions on each dive (e.g. Fig. 5). The surface

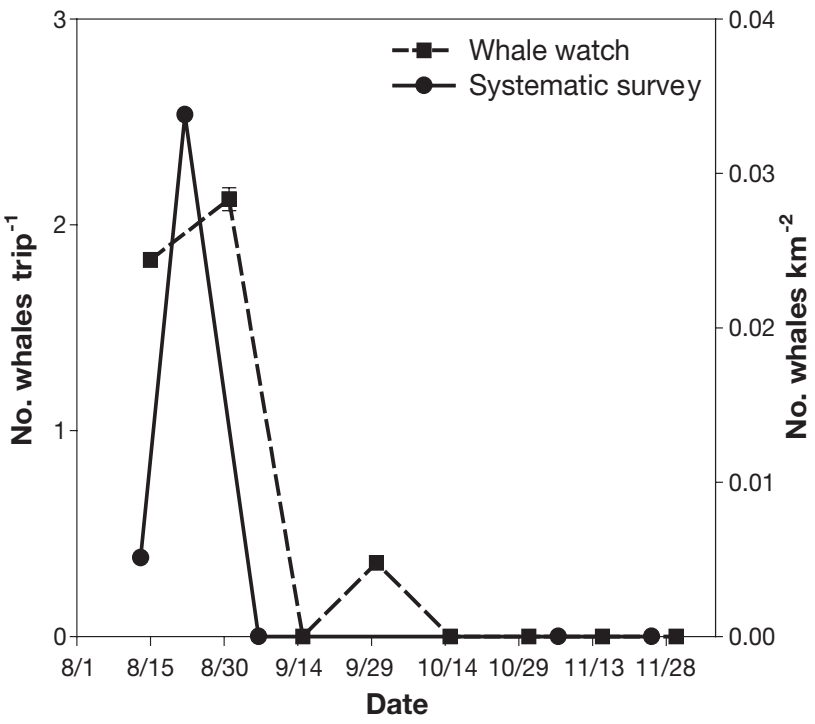

Fig. 4. Comparison of results of opportunistic whale-watch (Baleanoptera musculus) surveys and systematic marine mammal surveys between August and November, 1996, in Monterey Bay, California 

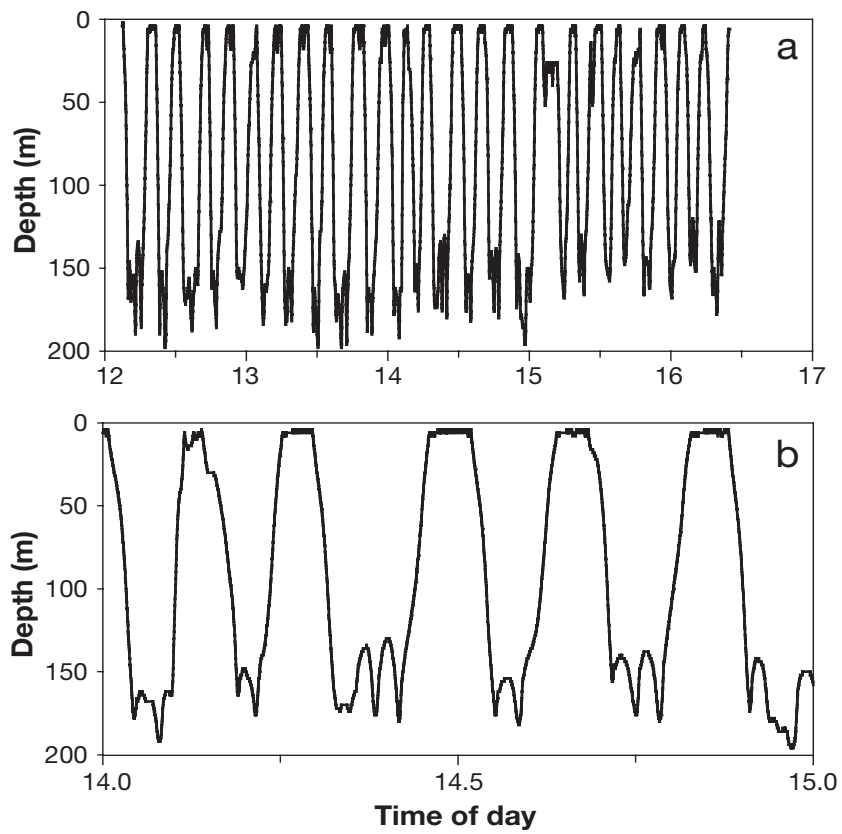

Fig. 5. Baleanoptera musculus. Diving behavior of blue whale tagged in small-area survey region on August 22, 1996, in Monterey Bay, California. (a) Entire $4.5 \mathrm{~h}$ record of diving behavior; (b) detailed $1 \mathrm{~h}$ record of diving behavior from data in (a)

tracks of both whales remained within $5 \mathrm{~km}$ of the canyon edge throughout the tag-deployment period, moving parallel to the canyon edge.

In August 1996, blue whales fed exclusively upon euphausiids. The proportion of different euphausiid species in the whale diet (percent by number) was sig-

Table 1. Thysanoessa spinifera and Euphausia pacifica. Percent composition and mean $( \pm \mathrm{SD})$ individual length of euphausiids collected in targeted net tows from August 14 to 21, 1996, in Monterey Bay, California

\begin{tabular}{|lcc|}
\hline $\begin{array}{l}\text { Targeted } \\
\text { tow }\end{array}$ & T. spinifera & E. pacifica \\
\hline A & 0 & $10.23 \pm 3.07 \mathrm{~mm}(\mathrm{n}=90)$ \\
& & $100.00 \%$ \\
B & 0 & $10.14 \pm 1.58 \mathrm{~mm}(\mathrm{n}=230)$ \\
& & $81.07 \%$ \\
C & $11.53 \%$ & $15.95 \pm 1.98 \mathrm{~mm}(\mathrm{n}=153)$ \\
& $16.82 \pm 3.51 \mathrm{~mm}(\mathrm{n}=50)$ & $70.56 \%$ \\
D & $29.44 \%$ & $97.49 \%$ \\
& $11.64 \pm 3.34 \mathrm{~mm}(\mathrm{n}=63)$ & $14.99 \pm 3.48 \mathrm{~mm}(\mathrm{n}=141)$ \\
E & $2.51 \%$ & $57.68 \%$ \\
& $18.33 \pm 2.26 \mathrm{~mm}(\mathrm{n}=75)$ & $10.98 \pm 3.30 \mathrm{~mm}(\mathrm{n}=148)$ \\
F & $40.08 \%$ & 0 \\
& $11.53 \pm 2.09 \mathrm{~mm}(\mathrm{n}=108)$ & $12.04 \pm 2.91 \mathrm{~mm}(\mathrm{n}=140)$ \\
G & $98.56 \%$ & \\
& $14.20 \pm 2.88 \mathrm{~mm}(\mathrm{n}=156)$ & \\
\hline
\end{tabular}

nificantly different from the composition of euphausiids in net samples $\left(\chi^{2}=455.55, \mathrm{df}=2, \mathrm{p}<0.001\right)$. Fecal sample analysis $(\mathrm{n}=5)$ revealed that blue whales in Monterey Bay fed primarily upon Thysanoessa spinifera $(80 \pm 22.6 \%)$ and Euphausia pacifica $(13 \pm 26.4 \%)$; other euphausiids accounted for $7( \pm 4.7) \%$ of their diet. Euphausiid species composition within net samples collected during the same period varied considerably between samples (Table 1), and consisted of 30.17 $( \pm 34.95) \%$ T. spinifera, $68.32( \pm 34.75) \%$ E. pacifica, and $1.51( \pm 2.56) \%$ other species. The mean size of $T$. spinifera and E. pacifica taken by whales was $19.3 \mathrm{~mm}$ $( \pm 1.53, \mathrm{n}=162)$, and $16.0 \mathrm{~mm}( \pm 2.05, \mathrm{n}=82)$, respectively. This was significantly larger than the size of $T$. spinifera and E. pacifica taken in net samples $(16.3 \mathrm{~mm} \pm 3.71, \mathrm{n}=100$ and $11.8 \mathrm{~mm} \pm 3.32, \mathrm{n}=100$, respectively). Student's $t$-test; $T$. spinfera: $t=9.12$, d.f. $=260, \mathrm{p}<0.001 ;$ E. pacifica: $t=9.99, \mathrm{df}=180$, $\mathrm{p}<0.001$ (Fig. 6).

\section{Euphausiid distribution, abundance, and composition}

The large-area survey conducted on 13 to 14 August 1996 revealed euphausiid schools close to the offshore edge of the submarine canyon (Fig. 7). Mean backscattering strength of euphausiids in this survey was $7.4 \times$

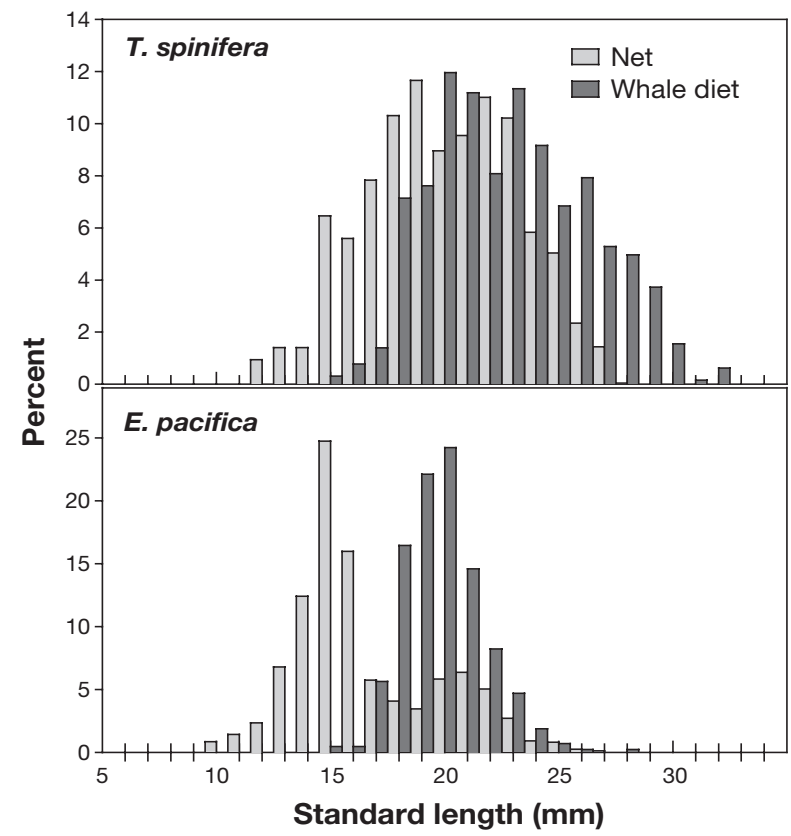

Fig. 6. Comparison of length distribution of euphausiids (mainly Thysanoessa spinifera and Euphausia pacifica) captured in bongo net samples with those estimated from Baleanoptera musculus fecal samples collected in August 1996 in Monterey Bay, California 


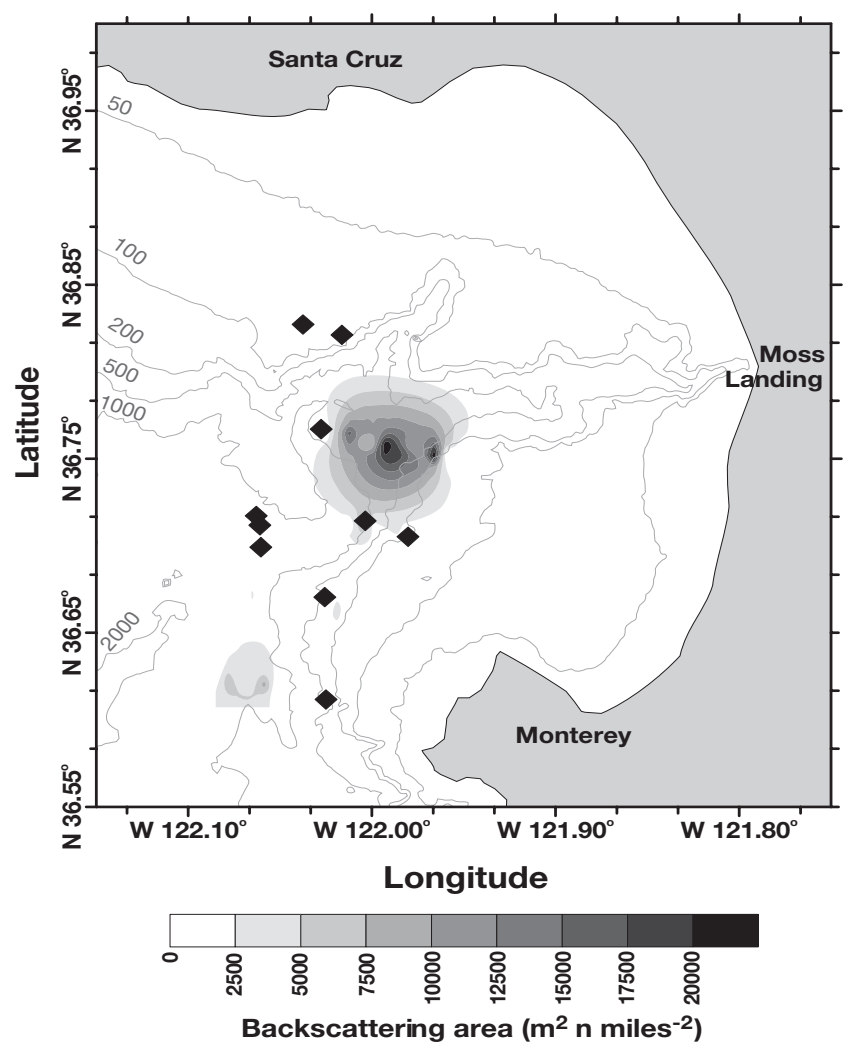

Fig. 7. Contoured euphausiid backscatter from August 13 to 14, 1996, survey in Monterey Bay, California. ( ) Baleanoptera musculus sightings during survey

$10^{-4} \mathrm{~m}^{2} \mathrm{~m}^{-2}\left( \pm 1.3 \times 10^{-4} \mathrm{SE}\right)$, which is equivalent to a mean density of $1.3 \mathrm{~g} \mathrm{~m}^{-3}( \pm 6.35 \mathrm{SE}), 39$ individuals $\mathrm{m}^{-3}$, or $260 \mathrm{~g} \mathrm{~m}^{-2}$. Blue whales encountered during this survey were also located over or close to the edge of the submarine canyon (Fig. 7). Small-area surveys revealed these canyon-edge euphausiid schools to be concentrated between 80 and $180 \mathrm{~m}$ depth, and averaged $15.1 \mathrm{~m}( \pm 8.38)$ in height $(\mathrm{N}=226,0.5 \mathrm{n}$ mile samples), with most euphausiid schools located between 120 and $160 \mathrm{~m}$ (Fig. 8) over water depths $>1000 \mathrm{~m}$. The mean integrated backscattering strength of these canyon-associated schools was $5.9 \times 10^{-3} \mathrm{~m}^{2} \mathrm{~m}^{-2}$ $\left( \pm 5.5 \times 10^{-4} \mathrm{SE}\right)$, which is equivalent to a mean density of $152.8 \mathrm{~g} \mathrm{~m}^{-3}( \pm 15.91 \mathrm{SE}), 4403$ individuals $\mathrm{m}^{-3}$, or $1847 \mathrm{~g} \mathrm{~m}^{-2}$ integrated over school depth.

There was considerable variability between spatially distinct euphausiid schools both with respect to species composition and individual size structure. Percent composition and mean size of Thysanoessa spinifera and Euphausia pacifica within the 7 targeted net samples conducted between August 14 and 21, 1996, are summarized in Table 1. The overall mean size for T. spinifera and E. pacifica individuals was 16.3 and $11.8 \mathrm{~mm}$ (see preceding subsection), respectively.
However, there were significant differences in the mean size of individuals between spatially distinct schools (Kruskal-Wallis: T. spinifera $H=89.91, \mathrm{p}<$ 0.001 , df $=2$; E. pacifica $H=380.23, \mathrm{p}<0.001$, df $=5$ ).

Net samples from May, August, and September 1996 revealed strong seasonal recruitment and growth for both Thysanoessa spinifera and Euphausia pacifica populations within Monterey Bay (Fig. 9). Juveniles made up the bulk of both populations in May of 1996, while adults became numerically dominant in August and September, although the persistent presence of juveniles within all samples indicated that recruitment was continuous throughout the summer.

\section{Seasonal abundance of zooplankton}

Daily averages (January 1 to November 7,1996 ) of ADCP backscatter were used to provide a continuous record of zooplankton abundance for Monterey Bay (Fig. 10). Early in the year (January to February) backscatter intensity was relatively high, with layers appearing near the surface and below $150 \mathrm{~m}$. By midMarch the deeper layer had disappeared and overall backscatter was at a minimum. Backscatter throughout

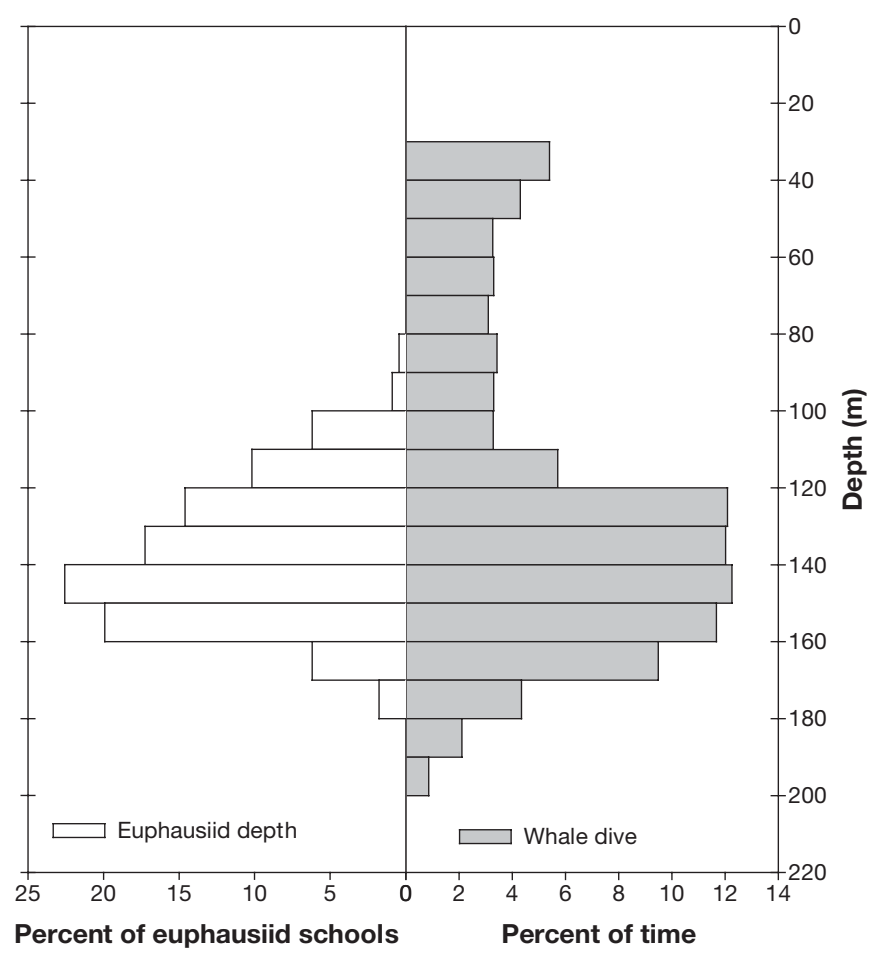

Fig. 8. Comparison of depth distribution of euphausiid schools encountered in small-area surveys in Monterey Bay, California, with time spent at depth by 2 foraging Baleanoptera musculus tagged in same area in August 1996 


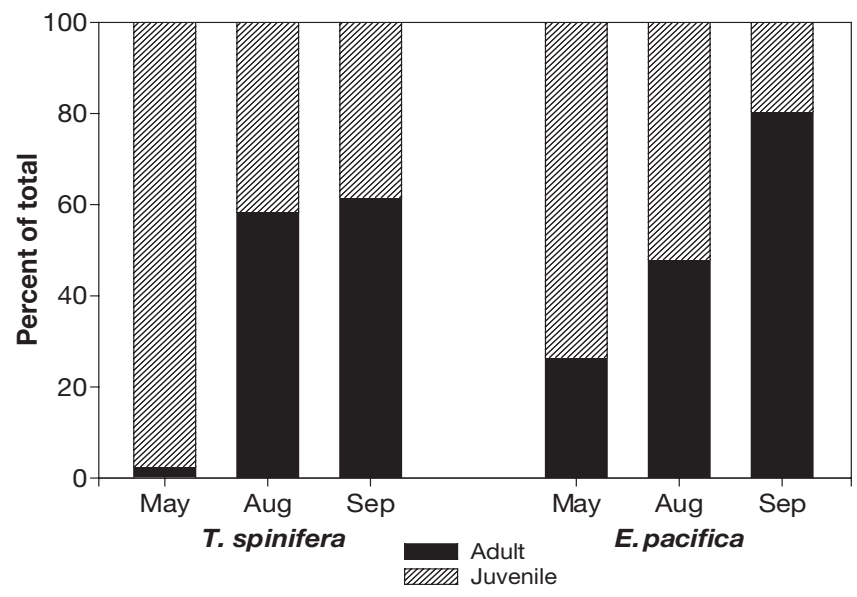

Fig. 9. Thysanoessa spinifera and Euphausia pacifica. Age composition of euphausiids captured in bongo net samples in Monterey Bay, California, in 1996

the water column abruptly increased in July, including zooplankton backscatter at the deeper depths. High levels of backscatter persisted until mid-October, when backscatter levels diminished. However, the deeper layer of backscatter persisted into November, but at a diminished intensity.

\section{Seasonal patterns in oceanography}

Oceanographic climatology for Monterey Bay between 1992 and 1996 is summarized in Fig. 3. Upwelling-favorable winds led to a shift in the upwelling index from negative values (downwelling) to positive values (upwelling) in late February. Upwelling persisted until late summer. This upwelling led to a sharp decline in sea-surface temperature, indicating that cold nutrientrich water had reached the surface by midMarch. This was linked to a mid-March increase in primary production, which was also reflected in integrated chlorophyll values.

\section{DISCUSSION}

\section{Whale diet and euphausiid composition}

Blue whales foraging in Monterey Bay fed exclusively upon the epipelagic euphausiids Thysanoessa spinifera and Euphausia pacifica in proportions that were different from the overall composition in net samples. Schoenherr (1991) found that blue whales in Monterey Bay fed primarily upon T. spinifera, and while she did not report E. pacifica in their diet, it is likely that it composed much of the unidentifiable material in her samples. This is supported by the observation that E. pacifica was the second-most common euphausiid species she found in deep net tows. Because her study focused upon surface feeding whales, and $T$. spinifera is found in the upper portion of the water column, where it often forms surface swarms (Youngbluth 1976, Smith \& Adams 1988), it is possible that the importance of this species was overemphasized in her study. Similar to our study, Fiedler et al. (1998) found that the dominant species in net tows in the vicinity of foraging blue whales and blue whale fecal samples near the Channel Islands, California, were T. spinifera and E. pacifica.

Fiedler et al. (1998) speculated that foraging blue whales preferentially feed upon adult euphausiids. Comparison of our blue whale diet and net sample data in Monterey Bay support this hypothesis: euphausiids found in whale fecal samples were significantly larger than those taken in net samples. This observation may have resulted from bias toward less mobile euphausiids in net samples, escape of smaller euphausiids through the baleen of foraging whales, or preferential targeting of adult euphausiid schools by foraging whales. We believe that blue whales preferentially target areas where adult euphausiids are encountered. Euphausiid schools are highly variable in species and size structure at the spatial scale of Monterey Bay (Table 1). Our direct measurement of the diving behavior of whales in Monterey Bay (Fig. 5) indicates that whales concentrate their foraging activity on deeper layers of euphausiids located between 150 and $200 \mathrm{~m}$. Several investigators (e.g. Bollens et al. 1992, Lavaniegos 1996) have found

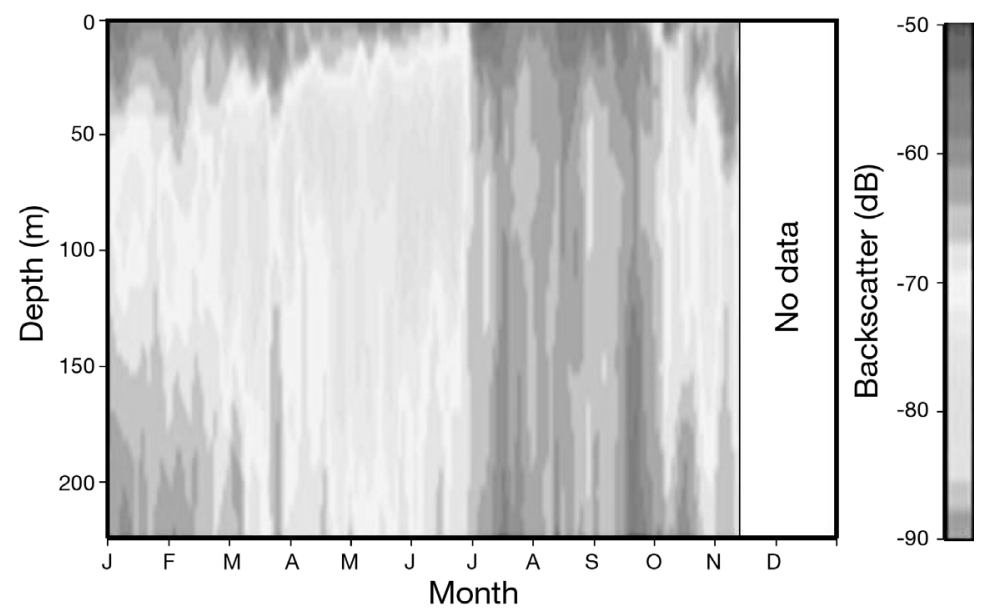

Fig. 10. Seasonal density of zooplankton by depth from daily averages of backscatter of acoustic Doppler current profiler (ADCP). Data are from 1996. ADCP located on mooring at Stn M1, Monterey Bay, California 
that later life-history stages of euphausiids are found deeper in the water column. Wishner et al. (1995) also suggested that right whales select copepod aggregations with older lifestages.

\section{Blue whale foraging}

The distribution of blue whale sightings and euphausiid densities (Figs. 2 \& 7), and the daytime vertical distribution of whale dives and euphausiids (Fig. 8) indicate that whale foraging effort is concentrated on dense euphausiid schools associated with the Monterey Submarine Canyon. Whales dove directly down to the densest aggregations of euphausiids between 150 and $200 \mathrm{~m}$ on the canyon edge. Studies of blue whales foraging off the Channel Islands, California, have reported similar behavior (Croll et al. 1998, Fiedler et al. 1998).

Monterey Bay is a region of relatively high summer euphausiid abundance. The mean krill densities we measured in Monterey Bay $\left(260 \mathrm{~g} \mathrm{~m}^{-2}\right.$ ) were greater than those measured in other regions of high euphausiid abundance (e.g. 1 to $3 \mathrm{~g} \mathrm{~m}^{-2}$, Gulf of Maine: Greene et al. 1991; 30 to $101 \mathrm{~g} \mathrm{~m}^{-2}$, South Shetland Islands: Hewitt \& Demer 1993; 20.6 to $61.6 \mathrm{~g} \mathrm{~m}^{-2}$, Weddell Sea: Brierly et al. 2002). Blue whales sought euphausiid patches in Monterey Bay that were much greater than the mean densities available in the Bay (1847 vs $260 \mathrm{~g} \mathrm{~m}^{-2}$ ). Because our measurements were directed at patches where whales were observed foraging, we feel that this provides, for the first time, an estimate of prey densities for large rorquals. This density is close to the maximum densities estimated for Thysanoessa raschi and Meganyctiphanes norvegica (127 to $1660 \mathrm{~g} \mathrm{~m}^{-2}$ ) in the Gulf of St. Lawrence, an important blue whale foraging area (Simard \& Lavoie 1999). Thus, blue whales appear to forage at euphausiid densities close to the maximum measured.

How do these densities compare with prey densities observed for other zooplanktivores? Brodie et al. (1978) estimated that fin whales Balaenoptera edeni required prey concentrations of at least $17.5 \mathrm{~g} \mathrm{~m}^{-3}$ to meet their daily energy requirements. Although mean euphausiid densities in Monterey Bay $\left(1.3 \mathrm{~g} \mathrm{~m}^{-3}\right)$ were much lower than this, such densities were readily available at the canyon edge. Wishner et al. (1995) found that zooplankton densities in regions where right whales foraged in the SW Gulf of Maine were approximately 3 times the mean densities in the region (whale feeding densities averaged 3.1 to $5.9 \mathrm{~g} \mathrm{~m}^{-3}$ compared to 1.1 to $3.6 \mathrm{~g} \mathrm{~m}^{-3}$ where whales were not foraging). In a related study, Macaulay et al. (1995), using hydroacoustic surveys, estimated zooplankton density where right whales were foraging at 18 to $25 \mathrm{~g} \mathrm{~m}^{-3}$ (compared to 1 to $5 \mathrm{~g} \mathrm{~m}^{-3}$ where whales were not foraging). Sims \& Quayle (1998) found that the basking shark (another large filter-feeder) preferentially feed on the richest, most profitable zooplankton patches associated with fronts. In a related study, Sims (1999) found zooplankton densities in regions where sharks foraged were 3.2 times that of median zooplankton densities. Compared to these large zooplanktivores, blue whales seek extremely dense aggregations of zooplankton (152.8 g $\mathrm{m}^{-3}$ ) to meet their metabolic needs. Such densities can be found only in regions that support exceptionally high productivity.

\section{Factors leading to whale foraging patches}

Due to their high prey demand, blue whales must seek regions of exceptionally high productivity. The association of cetaceans with submarine canyons has been reported elsewhere (Hooker et al. 1999). Schoenherr (1991) first reported the association of blue whales with the steep topography of the Monterey Submarine Canyon, and our study confirms this observation. This association could result from whales directly responding to physical patterns in water temperature or currents in this region, or they may be associating indirectly via patterns in the distribution of biological resources that are directly responding to the canyon edge habitat. Water temperature and current patterns in the upper portion of the water column in Monterey Bay are more strongly influenced by upwelling north of the Bay than the canyon feature itself (Rosenfeld et al. 1994, Paduan \& Rosenfeld 1996), so it is unlikely that whales are directly associating with the canyon. Instead, both our study and Schoenherr's (1991) demonstrate that whales are aggregating on the canyon edge as they exploit dense schools of euphausiids associated with the canyon.

There are several factors that may lead to the development of dense aggregations of euphausiids at the canyon edge. Euphausiids are generally found in regions of high primary productivity (Brinton 1962, Mauchline 1980). In most areas in which they have been studied, adult epipelagic euphausiids such as Thysanoessa spinifera and Euphausia pacifica undergo diel migrations to depths in excess of $100 \mathrm{~m}$ (e.g. Greenlaw 1979, Hovekamp 1989, Bollens et al. 1992). Along the central California coast, the continental shelf break occurs at a depth of around 100 to $150 \mathrm{~m}$. Some of the most productive coastal waters along the California coast are found inshore of the shelf break, downstream of upwelling centers in waters less than $100 \mathrm{~m}$ deep (Reid et al. 1958, Wooster \& Reid 1963, Rosenfeld et al. 1994, Pennington \& Chavez 2000). Topographic breaks in the shelf such as the Monterey Submarine 
Canyon provide water depths in excess of $1000 \mathrm{~m}$ within $10 \mathrm{n}$ miles of shore, down-current from upwelling centers such as Pt. Ano Nuevo. Euphausiids that aggregate in these topographic breaks (e.g. the Monterey Submarine Canyon) are able to undergo diel migrations in excess of $100 \mathrm{~m}$ (presumably to minimize predation in daylight hours) while remaining in the highly productive, recently upwelled, near-shore waters (Rosenfeld et al. 1994).

The current dynamics of the canyon may also help reduce the need for euphausiids to swim in relation to surface currents and thus reduce energetic costs for euphausiids during the day. Below $100 \mathrm{~m}$ over the continental slope off central California, the dominant current is the northward-flowing California Undercurrent (Chelton 1984, Wickham et al. 1987, Chelton et al. 1988, Tisch et al. 1992). Ramp et al. (1997) found that northward currents at $100 \mathrm{~m}$ depth off Pt. Sur, California (approximately $60 \mathrm{~km}$ south, outside Monterey Bay) averaged $9.5 \mathrm{~cm} \mathrm{~s}^{-1}$. In contrast, currents at $100 \mathrm{~m}$ in the Monterey Submarine Canyon where euphausiids were aggregated averaged $<2 \mathrm{~cm} \mathrm{~s}^{-1}$ (F. P. Chavez unpubl. obs.). Thus, the Monterey Submarine Canyon habitat would provide (1) the opportunity for high energy gain for euphausiids during nighttime surface grazing due to its location downstream from an upwelling center, (2) a refuge from daytime predation as euphausiids can migrate to depths in excess of $100 \mathrm{~m}$ in the canyon, and (3) reduced swimming energy output during daytime schooling at depth due to reduced canyon-slope currents. Similar factors probably serve to concentrate euphausiids in other blue whale foraging areas off the California and Baja California coasts, where bottom topography provides deepwater access downstream from coastal upwelling centers (e.g. Santa Barbara Channel, Cordell Bank, Gulf of the Farallons, Punta Eugenia, Bahia Loreto).

\section{Seasonal patterns in oceanographic processes and whale abundance}

Coastal upwelling occurs seasonally along the coast of California (Reid et al. 1958, Wooster \& Reid 1963, Bakun et al. 1974, Bakun 1990). Equatorward winds develop in the spring due to movements of the Aleutian low-pressure system and North Pacific high. These winds act in combination with the Coriolis force, leading to a positive curl in the wind stress that moves an Ekman layer of surface waters offshore. This draws cold, nutrient-rich deeper water to the surface that extends as a broad band of cool water 10s of kilometers along the California coast (reviewed by Hickey 1979). In some regions, fronts, plumes and eddies can develop, extending $>100 \mathrm{~km}$ offshore (Abbot \& Zion
1985, Kelley 1985, Strub et al. 1991). This seasonal upwelling of nutrient-rich water supports high primary production and associated higher trophic levels (Reid et al. 1958, Barber \& Smith 1981, Hutchings et al. 1995).

In Monterey Bay, high levels of primary and zooplankton production are supported by springtime upwelling to the north of the bay between Pt. Año Nuevo and Davenport (Rosenfeld et al. 1994, Service et al. 1998, Pennington \& Chavez 2000). Skogsberg (1936) defined 3 oceanographic periods in the Monterey Bay and the California Current: (1) a spring/summer 'upwelling season', (2) a summer/fall 'oceanic season', and (3) a winter 'Davidson Current season'. These periods have generally been accepted by subsequent studies (Barham 1957, Bolin \& Abbot 1963, Pennington \& Chavez 2000). During the upwelling season, pulses of NW wind lasting a few days generally start around February, supporting pulses of high primary production which lag the initiation of upwelling by 6 to $10 \mathrm{~d}$ (Dugdale \& Wilderson 1989, Service et al. 1998). Depending on weather conditions, these pulses can sporadically occur into the oceanic season (Pennington \& Chavez 2000). Fewer studies have examined seasonal changes in secondary productivity, but Barham (1957) found that zooplankton abundance was highest in the late upwelling and early oceanic seasons.

Physical and biological oceanographic climatologies for Monterey Bay 1992 to 1996 confirm these seasonal patterns and demonstrate linkages between physical forcing, sea surface temperature and productivity in the Bay (Fig. 3). Increased wind-forcing in February leads to decreases in sea-surface temperature (upwelling) and increases in primary production and surface chlorophyll. However, it is less clear how these events are linked to seasonal patterns in zooplankton and blue whale abundance.

In a long-term study of productivity off Pt. Conception, California, Hayward \& Venrick (1998) found close linkages between physical forcing and integrated chlorophyll values. They also found that while integrated chlorophyll peaked in spring, zooplankton biomass did not peak until 1 to 4 mo later. In Monterey Bay, moderate zooplankton abundance appears to persist through February, with distinct scattering layers near the surface and below $150 \mathrm{~m}$ (Fig. 10). However, by March, zooplankton backscatter is considerably reduced, and the deeper backscatter layer is no longer present. It is not until July, several months after the seasonal increase in primary production (Fig. 3) and the initiation of the oceanic period, that zooplankton backscatter dramatically increases. At this time, backscatter is relatively high throughout the water column, persisting into October. The seasonal arrival of blue whales in Monterey Bay appears to be linked to this dramatic increase in zooplankton in July. 
The July increase in zooplankton density and arrival of blue whales in Monterey Bay may be explained by 2 non-exclusive hypotheses. First, ontogenetic development of euphausiid larvae, spawned from overwintering adults between January and February, may lead to a July recruitment of adult euphausiids. This hypothesis is supported by the changes in euphausiid development from net samples in May (mostly larval euphausiids) into August and September (predominantly adult euphausiids) (Fig. 9). Second, an abrupt decrease in the intensity and frequency of upwelling-favorable winds from a peak in June into July leads to a shoreward collapse of offshore productivity toward the coast (Abbot \& Barksdale 1991). This would lead to a seasonal peak in euphausiid density, as euphausiids tracking this shoreward collapse arrive in Monterey Bay. Both of these factors would explain seasonally high densities of adult euphausiids in Monterey Bay, leading to the appearance of blue whales in the Bay in July.

An interesting parallel to our study is that of Robison et al. (1998), who examined the 1993 to 1995 seasonal abundance in Monterey Bay of Nanomia bijuga, a predatory siphonophore that feeds primarily upon the same euphausiid species as blue whales (Alvarino 1971, Mackie 1985). Robison et al. (1998) found that during the day, siphonophores were concentrated between 200 and $400 \mathrm{~m}$, and similar to our observation for blue whales, they found that siphonophore populations peaked in July, about 3 to 4 mo after the seasonal peak in primary production. Unlike blue whales, which seasonally migrate to Monterey Bay, Robison et al. (1998) hypothesized that the seasonal increase in Nanomia resulted either from onshore advection through the intrusion of offshore oceanic water due to decreased upwelling (essentially tracking the shoreward collapse of euphausiids), or in situ population growth of siphonophores.

\section{Prey resources and whale migration patterns}

We found that California blue whales foraging in the coastal upwelling zone sought extremely dense patches of euphausiids aggregated on the edge of the Monterey Bay Submarine Canyon. Spatially, high euphausiid densities result from the unique combination of the proximity of the deep canyon to an upstream coastal upwelling center. Temporally dense patches develop seasonally, lagging the seasonal increase in productivity by 3 to 4 mo. This lag may result from the temporal development of euphausiids spawned around the seasonal peak in primary production and the shoreward collapse of productivity as the intensity of coastal upwelling diminishes in the summer. Based upon the relationship we have described for Monterey Bay, we predict that the annual migratory movements of the California blue whale population reflect seasonal patterns in productivity in other foraging areas in the NE Pacific. Regions with different seasonal upwelling patterns and euphausiid species that have different life history traits will show temporal differences in peak euphausiid abundance and thus whale distribution and abundance. Due to their high prey requirements, California blue whales probably migrate seasonally between dense, ephemeral euphausiids patches that appear in southern/central California in the summer and fall, the Gulf of California in the winter, and the central Baja California Pacific coast in the spring. The large body size of blue whales can serve as a buffer from variability in pelagic productivity, allowing them to migrate long distances over long periods of time between regions of patchy and ephemeral productivity without feeding (Schoener \& Janzen 1968, Croll \& Tershy 2002). Further, the evolution of filter-feeding in whales permits large quantities of dense but ephemeral aggregations of prey to be consumed in the limited time available (Croll \& Tershy 2002).

\section{CONCLUSIONS}

Most marine mammals are apex carnivores adapted to feed on dense, patchily distributed aggregations of schooling prey (Gaskin 1982, Riedman 1990). This may result from low standing biomass and high turnover of small-sized primary producers that respond rapidly to nutrient availability compared to terrestrial systems (Steele 1985). Due to the physical dynamics of marine ecosystems, this productivity tends to be patchy and ephemeral and the dominant marine grazers (e.g. schooling crustaceans and fishes that are the primary prey of marine mammals) also have patchy but dense distributions near regions of high primary production. Efforts to correlate the distribution and abundance of apex predators to indirect indicators of prey abundance (e.g. sea-surface temperature, surface chlorophyll) can be greatly improved by incorporating temporal and spatial variability generated by intermediate biological processes (Horne \& Schneider 1994).

The annual increase in the abundance of blue whales in Monterey Bay is linked to wind-driven upwelling, but these linkages occur through a sequence of bottom-up biological processes. Thus, the annual peak in primary production temporally lags increased physical forcing. In turn, due to population demographic processes, annual increases in adult euphausiid abundance lag peak primary productivity. Thus, annual increases in whale abundance lag both primary production and physical forcing. Ocean dynamics translate these temporal lags into spatial mismatches 
between indices of physical forcing and regions of high prey abundance. For models to accurately predict the distribution, abundance and annual production of pelagic predators, these processes must be taken into consideration.

Globally, blue whales are classified as endangered by the International Union for Conservation of Nature. Extensive exploitation has severely reduced most populations, and existing data indicate that they remain small (Clapham et al. 1999). Due to low statistical power, it is not possible to detect recovery in most populations (Gerrodette 1995), but worldwide the California blue whale population is the only one that appears to be recovering strongly (Clapham et al. 1999). Unlike most other populations, upwelling centers (coastal and tidal) comprise an important foraging habitat for the California blue whale population (Reilly \& Thayer 1990, Gendron 1992, Tershy 1992, Croll et al. 1998, Fiedler et al. 1998). The seasonally dependable, dense aggregations of euphausiids generated in regions where deep waters are juxtaposed to these upwelling centers may play a key role in the recovery of this population in comparison to others. The ecological importance of such habitats supports Hooker et al.'s (1999) suggestion that cetacean distribution, particularly in relation to local geomorphology and oceanography, could play a role in designating and managing marine protected areas. In California, 5 important blue whale foraging areas (Gulf of the Farallons, Cordell Bank, Monterey Bay, Channel Islands, and Bahia Loreto) currently are designated as marine sanctuaries.

Acknowledgements. Our thanks to a myriad of people who have directly helped in field studies and indirectly helped us develop the intellectual framework to understand these animals. David Demer and Roger Hewitt (NOAA/NMFS) provided support in hydroacoustic data collection and processing, Tom Kiekhefer processed whale fecal samples, Jennifer Emery helped process hydroacoustic records, Reiko Michisaki helped process physical and biological oceanographic data, Dan Costa, Jim Harvey, and Terrie Williams enabled us to pursue the temporal approach, Charles Greene, the UCSC Institute of Marine Sciences, and the Bioacoustics Workshop provided support for shipboard surveys, Nancy Gong and Kit Clark sorted zooplankton samples. Of equal importance has been the support and goodwill of the personnel of the RV 'John Martin', RV 'David Johnston', and the MLML Ship Operations, especially Tracy Thomas, Michael Prince, John Douglas, Lee Bradford, and Maria Kaanapu. James Estes and Sascha Hooker provided useful comments on the manuscript. D.A.C. and B.R.T. were supported in part by Office of Naval Research Grants N00014-95-10646 and N00014-99-10192, Marine Acoustics Contract MAI9811, and National Oceanic and Atmospheric Administration contract 40ABNF600916. D.A.C. and B.M. were supported in part by Department of Energy Western Global Environmental Change Grant 990196. The Homeland Foundation, the Monterey Bay National Marine Sanctuary, and the Channel Islands National Marine Sanctuary provided additional research support.

\section{LITERATURE CITED}

Abbot MR, Barksdale B (1991) Phytoplankton pigment patterns and wind forcing off central California. J Geophys Res 96:14649-14667

Abbot MR, Zion PM (1985) Satellite observations of phytoplankton variability during an upwelling event. Cont Shelf Res 4:661-680

Alvarino A (1971) Siphonophores of the Pacific with a review of the world distribution. Bull Scripps Inst Oceanogr Univ Calif Tech Ser 16:432

Bakun A (1990) Global climate change and intensification of coastal ocean upwelling. Science 247:198-201

Bakun A, Nelson CS (1991) The seasonal cycle of wind stress curl in subtropical eastern boundary current regions. J Phys Oceanogr 21:1815-1834

Bakun A, McLain DR, Mayo PV (1974) The mean annual cycle of coastal upwelling western North America as observed from surface measurements. Fish Bull US Dep Comm 72: 843-844

Barber RT, Smith RL (1981) Coastal upwelling ecosystems. In: Longhurst A (ed) Analysis of marine ecosystems. Academic Press, New York, p 31-68

Barham EG (1957) The ecology of sonic scattering layer in the Monterey Bay area, California. Stanford, Palo Alto

Barlow J (1994) Abundance of large whales in California coastal waters: a comparison of ship surveys in 1979/80 and in 1991. Rep Int Whal Comm 44:399-406

Bolin RL, Abbot DP (1963) Studies of the marine climate and phytoplankton of the central coastal area of California, 1954-1960. Calif Coop Ocean Fish Investig Rep 9:23-45

Bollens SM, Frost BW, Lin TS (1992) Recruitment, growth, and diel vertical migration of Euphausia pacifica in a temperate fjord. Mar Biol 114:219-228

Bowen WD (1997) Role of marine mammals in aquatic ecosystems. Mar Ecol Prog Ser 158:267-274

Boyd IL, Arnbom T (1991) Diving behavior in relation to water temperature in the southern elepant seal: foraging implications. Polar Biol 11:259-266

Brierly AS, Brandon MA, Watkins JL (1998) An assessment of the utility of an acoustic doppler current profiler for biomass estimation. Deep-Sea Res I 45:1555-1573

Brierly AS, Fernandez PG, Brandon MA, Armstrong F and 8 others (2002) Antarctic krill under sea ice: elevated abundance in a narrow band just south of ice edge. Science 295:1890-1892

Brinton E (1962) The distribution of Pacific euphausiids. Bull Scripps Inst Oceanogr 8:51-269

Brodie PF, Sameoto DD, Sheldon RW (1978) Population densities of euphausiids off Nova Scotia as indicated by net samples, whale stomach contents, and sonar. Limnol Oceanogr 23:1264-1267

Buchholz F, Buchholz C, Reppin J, Fischer J (1995) Diel vertical migrations of Meganyctiphanes norvegica in the Kattegat: comparison of net catches and measurements with acoustic Doppler current profilers. Helgol Meeresunters 49:849-866

Buckland ST, Anderson DR, Burnham KP, Laake JL, Borchers DL, Thomas L (1993) Distance sampling: estimating abundance of biological populations. Chapman \& Hall, London

Burnham KP, Anderson DR, Laake JL (1980) Estimation of density from line transect sampling of biological populations. Wildl Monogr 72:202

Carpenter SR, Kitchell JF (1993) The trophic cascade in lakes: synthesis of ecosystem experiments. Bull Ecol Soc Am 74: 186-187

Carpenter SR, Cole JJ, Hodgson JR, Kitchell JF and 6 others 
(2001) Trophic cascades, nutrients, and lake productivity: whole-lake experiments. Ecol Monogr 71:163-186

Chavez FP, Barber RT, Huyer A, Kosro PM, Ramp SR, Stanton T, Rojas de Mendiola B (1991) Horizontal advection and the distribution of nutrients in the coastal transition zone off northern California: effects on primary production, phytoplankton biomass, and species composition. J Geophys Res 96:14833-14848

Chelton DB (1984) Seasonal variation of alongshore geostrophic velocity off Central California. J Geophys Res 92:3473-3486

Chelton DB, Bratkovich AW, Bernstein RL, Kosro PM (1988) Poleward flow off central California during the spring and summer of 1981 and 1984. J Geophys Res 93:10604-10620

Clapham PJ, Young SB, Brownell RL (1999) Baleen whales: conservation issues and the status of the most endangered populations. Mamm Rev 29:35-60

Croll DA, Tershy BR (2002) Filter feeding. In: Perrin WF, Wursig B, Thewissen JGM (eds) Encyclopedia of marine mammals. Academic Press, San Diego, p 428-432

Croll DA, Tershy BR, Hewitt R, Demer D, Hayes S, Fiedler P, Popp J, Lopez VL (1998) An integrated approach to the foraging ecology of marine birds and mammals. Deep-Sea Res II 45:1353-1371

Croll DA, Clark CW, Calambokidis J, Ellison WT, Tershy BR (2001) Effect of anthropogenic low-frequency noise on the foraging ecology of Balaenoptera whales. Anim Conserv $4: 13-27$

Dugdale RC, Wilderson FP (1989) New production in the upwelling center at Point Conception, California: temporal and spatial patterns. Deep-Sea Res II 36:985-1007

Elphick CS, Hunt GL Jr (1993) Variations in the distributions of marine birds with water mass in the northern Bering Sea. Condor 95:33-44

Erlinge S, Göransson G, Högstedt G, Jansson G and 5 others (1984) Can vertebrate predators regulate their prey? Am Nat 123:125-133

Estes JA, Smith NS, Palmissano JF (1978) Sea otter predation and community organization in the western Aleutian Islands, Alaska. Ecology 59:822-833

Fiedler PC, Reilly SB, Hewitt RP, Demer D and 6 others (1998) Blue whale habitat and prey in the California Channel Islands. Deep-Sea Res II 45:1781-1801

Forney KA, Barlow J (1998) Seasonal patterns in the abundance and distribution of California Cetaceans, 19911992. Mar Mamm Sci 14:460-489

Gaskin DE (1982) The ecology of whales and dolphins. Heinemann, London

Gendron D (1992) Population structure of daytime surface swarms of Nyctaphanes simplex in the Gulf of California. Mar Ecol Prog Ser 87:1-6

Gerrodette T (1995) The ability of IDCR cruises to detect changes in blue whale population size. Rep Int Whal Comm 45:271-272

Greene CH, Stanton TK, Wiebe PH, McClatchie S (1991) Acoustic estimates of Antarctic krill. Nature 349:110

Greenlaw CF (1979) Acoustical estimation of zooplankton populations. Limnol Oceanogr 24:226-242

Griffiths G, Diaz JI (1996) Comparison of acoustic backscattering measurements from a ship-mounted acoustic Doppler current profiler and an EK500 scientific echosounder. ICES J Mar Sci 53:487-491

Harrison NM, Hunt GLJ, Cooney RT (1990) Front affecting the distribution of seabirds in the northern Bering Sea. Polar Res 8:29-31

Hayward TL, Venrick EL (1998) Nearsurface pattern in the California Current: coupling between physical and bio- logical structure. Deep-Sea Res II 45:1617-1638

Hewitt RP, Demer DA (1993) Dispersion and abundance of Antarctic krill in the vicinity of Elephant Island in the 1992 austral summer. Mar Ecol Prog Ser 99:29-39

Hickey BM (1979) The California Current system-hypotheses and facts. Progr Oceanogr 8:191-279

Holm-Hansen O, Lorenzen CJ, Holmes R, Strickland JD (1965) Fluorometric determination of chlorophyll. J Cons Int Explor Mer 30:3-15

Hooker SK, Whitehead H, Gowans S (1999) Marine protected areas design and the spatial and temporal distribution of cetaceans in a submarine canyon. Conserv Biol 13:1-12

Horne JK, Schneider DC (1994) Lack of spatial coherence of predators with prey-a bioenergetic explanation for Atlantic cod feeding on capelin. J Fish Biol 45:191-207

Hovekamp S (1989) Avoidance of nets by Euphausia pacifica in Dabob Bay. J Plankton Res 11:907-924

Hutchings L, Pitcher GC, Probyn TA, Bailey GW (1995) The chemical and biological consequences of coastal upwelling. In: Summerhayes CP, Emeis KC, Angel MV, Smith RL, and Zeitzschel B (eds) Upwelling in the ocean: modern processes and ancient records. Wiley \& Sons, New York, p 64-81

Johannesson KA, Mitson RB (1983) Fisheries acoustics: a practical manual for aquatic biomass estimation. FAO Fish Tech Pap 240:249

Kelley KA (1985) The influence of winds and topography on the sea surface temperature patterns over the California northern slope. J Geophys Res 90:11783-11798

Kenney RD, Winn HE, Macaulay MC (1995) Cetaceans in the great south channel, 1979-1989: right whale (Eubalaena glacialis). Cont Shelf Res 15:385-414

Kieckhefer TR (1992) Feeding ecology of humpack whales in continental shelf waters near Cordell Bank, California. Master's thesis, Moss Landing Marine Laboratories, Moss Landing, CA

Lavaniegos BE (1996) Vertical distribution of euphausiid life stages in waters adjacent to Baja California. US Natl Mar Fish Serv Fish Bull 94:300-312

Macaulay MC, Wishner KF, Daly KL (1995) Acoustic scattering from zooplankton and micronekton in relation to a whale feeding site near Georges Bank and Cape Cod. Cont Shelf Res 15:509-537

Mackie GO (1985) Midwater macrozooplankton of British Columbia studied by submersible PISCES IV. J Plankton Res 7:753-777

Mauchline J (1980) The biology of euphausiids. Adv Mar Biol $18: 373-623$

Mehlum F, Hunt GL, Decker MB, Nordlund N (1998) Hydrographic features, cetaceans and the foraging of thickbilled murres and other marine birds in the northwestern Barents Sea. Arctic 51:243-252

Paduan JD, Rosenfeld LK (1996) Remotely sensed surface currents in Monterey Bay from shore-based HF radar (coastal ocean dynamics application radar). J Geophys Res 101: 20669-20686

Paine R (1966) Food web complexity and species diversity. Am Nat 122:45-52

Parsons TR, Maita Y, Lalli CM (1984) A manual of chemical and biological methods for seawater analysis. Pergamon Press, New York

Payne PM, Wiley DN, Young SB, Pittman S, Clapham PJ, Jossi JW (1990) Recent fluctuations in the abundance of baleen whales in the southern Gulf of Maine in relation to changes in selected prey. Fish Bull US Dep Comm 88: 687-696

Pennington JT, Chavez FP (2000) Seasonal fluctuations of 
temperature, salinity, nitrate, chlorophyll and primary production at station H3/M1 over 1989-1996 in Monterey Bay, California. Deep-Sea Res II 47:947-973

Piatt JF, Methaven DA (1992) Threshold foraging behavior in baleen whales. Mar Ecol Prog Ser 84:205-210

Polis GA, Hurd SD, Jackson CT, Pinero FS (1997) El Niño effects on the dynamics and control of an island ecosystem in the Gulf of California. Ecology 78:1884-1897

Polis GA, Hurd SD, Jackson CT, Sanchez-Pinero F (1998) Multifactor population limitation: variable spatial and temporal control of spiders on Gulf of California Island. Ecology 79:490-502

Ramp SR, Rosenfeld LK, Tisch TD, Hicks MR (1997) Moored observations of the current and temperature structure over the continental slow off central California. 1. A basic description of the variability. J Geophys Res 102: 22877-22902

Reid JL, Roden GI, Wyllie JG (1958) Studies of the California current system. Calif Coop Investig Prog Rep 1:29-56

Reilly SB, Thayer VG (1990) Blue whale (Balaenoptera musculus) distribution in the eastern tropical Pacific. Mar Mamm Sci 6:265-277

Rice DW (1978) Blue whale. In: Haley D (ed) Marine mammals of the Eastern Pacific and Arctic waters. Pacific Search Press, Seattle, p 30-35

Riedman M (1990) The pinnipeds seals, sea lions, and walruses. University of California Press, Berkeley

Robison BH, Reisenbichler KR, Sherlock RE, Silguero JMB, Chavez FP (1998) Seasonal abundance of the siphonophore, Nanomia bijuga, in Monterey Bay. Deep-Sea Res II 45:1741-1751

Rosenfeld LK, Schwing FB, Garfield N, Tracy DE (1994) Bifurcated flow from an upwelling center: a cold water source for Monterey Bay. Cont Shelf Res 14:931-964

Russell RW, Harrison NM, Hunt GL (1999) Foraging at a front: hydrography, zooplankton, and avian planktivory in the northern Bering Sea. Mar Ecol Prog Ser 77-93

Schoener TW, Janzen DH (1968) Notes on environmental determinants of tropical versus temperate insect size patterns. Am Nat 102:207-224

Schoenherr JR (1991) Blue whales feeding on high concentrations of euphausiids around Monterey Submarine Canyon. Can J Zool 69:583-594

Service SK, Rice JA, Chavez FP (1998) Relationship between physical and biological variables durinig the upwelling period in Monterey Bay, CA. Deep-Sea Res II 45: 1669-1685

Shepard FP (1973) Submarine geology. Harper \& Row, New York

Simard Y, Lavoie D (1999) The rich krill aggregation of the Saguenay-St. Lawrence Marine Park: hydroacoustic and geostatistical biomass estimates, structure, variability, and significance for whales. Can J Fish Aquat Sci 56: 1182-1197

Sims DW (1999) Threshold foraging behaviour of basking sharks on zooplankton: life on an energetic knife-edge? Proc R Soc Lond B Biol Sci 266:1437-1443

Sims DW, Quayle VA (1998) Selective foraging behavior of basking sharks on zooplankton in a small-scale front. Nature 393:460-464

Editorial responsibility: Kenneth Sherman (Contributing Editor), Narragansett, Rhode Island, USA
Skogsberg T (1936) Hydrography of Monterey Bay, California: thermal conditions, 1929-1933. Trans Am Phil Soc 29: $1-152$

Smith S, Adams P (1988) Daytime swarms of Thysanoessa spinifera (Euphausiacea) in the Gulf of the Farallones, California. Bull Mar Sci 42:76-84

Steele JH (1985) Comparison of marine and terrestrial ecological systems. Nature 313:355-358

Strub PT, Kosro PM, Huyer A (1991) The nature of the cold filaments in the California Current system. J Geophys Res 96:14743-14768

Terborg J (1988) The big things that run the world-a sequel to E. O. Wilson. Conserv Biol 2:402-403

Terborg J, Estes JA, Paquet P, Ralls K, Boyd-Heger D, Miller BJ, Noss RF (1999) The role of top carnivores in regulating terrestrial ecosystems. In: Soule ME and Terborgh J (eds) Continental conservation. Island Press, Washington, DC, p 39-64

Tershy BR (1992) Body size, diet, habitat use, and social behavior of Balaenoptera whales in the Gulf of California. J Mamm 73:477-486

Tisch TD, Ramp SR, Collins CA (1992) Observations of the geostrophic current and water mass characteristics off Point Sur, California, from May 1988 through November 1989. J Geophys Res 97:12535-12555

Tomilin AG (1967) Mammals of the USSR and adjacent countries. Israel Program for Scientific Translations, Jerusalem

Tynan CT (1998) Ecological importance of the southern boundary of the Antarctic Circumpolar Current. Nature 392:708-710

Venrick EL (1990) Phytoplankton in an oligotrophic ocean: species structure and interannual variability. Ecology 71 : $1547-1563$

Venrick EL, Hayward TL (1984) Determining chlorophyll on the 1984 CalCOFI surveys. Calif Coop Fish Investig Rep 25:74-78

Whitehead H, Glass C (1985) The significance of the Southeast Shoal of the Grand Bank to humpback whales and other cetacean species. Can J Zool 63:2617

Wickham JB, Bird AA, Mooers CNK (1987) Mean and variable flow over the central California continental margin. Cont Shelf Res 7:827-849

Winn HE, Goodyear JD, Kenney RD, Petricig RO (1995) Dive patterns of tagged right whales in the Great South Channel. Cont Shelf Res 7:827-849

Wishner KF, Schoenherr JR, Beardsley R, Chen C (1995) Abundance, distribution, and population structure of the copepod Calanus finmarchicus in a springtime right whale feeding area in the southwestern Gulf of Maine. Cont Shelf Res 15:475-507

Wooster WS, Reid JL (1963) Eastern boundary currents. In: Hill MH (ed) The sea, Vol 2. John Wiley, Hoboken, NJ, p 253-276

Yochem PK, Leatherwood S (1985) Blue whale Balaenoptera musculus (Linnaeus, 1758). In: Ridgway S, Harrison S (eds) Handbook of marine mammals, Vol 3. Academic Press, London, p 193-240

Youngbluth M (1976) Vertical distribution and diel migration of euphausiids in the central region of the California Current. Fish Bull Fish Wildl Serv US 74:925-936

Submitted: March 11, 2003; Accepted: September 29, 2004 Proofs received from author(s): March 8, 2005 